\title{
Does Trade Liberalization Reduce Poverty in Mali? Evidence from ARDL Bounds Testing Approach
}

\author{
Adjouro Togo ${ }^{1}$ \\ ${ }^{1}$ School of Economics, Shanghai University, Shanghai, China \\ Correspondence: Adjouro Togo, School of Economics, Shanghai University, 99 Shangda Road, Shanghai \\ 200444, China. Tel: 86-137-615-49054. E-mail: togo_manuel@yahoo.fr
}

Received: June 27, 2020

Accepted: July 28, 2020

Online Published: August 4, 2020

doi:10.5539/ijef.v12n9p11

URL: https://doi.org/10.5539/ijef.v12n9p11

\begin{abstract}
This paper investigates the impact of trade liberalization on poverty reduction in Mali over the period 1986-2018. Like Magombeyi and Odhiambo (2017), we will use three measures of poverty (namely per capita consumption, infant mortality rate and life expectancy) to capture its multidimensional aspects. Using the ARDL bounds testing approach, the findings indicate that there is a negative relationship between trade liberalization and three proxies of poverty reduction in the long-run. However, it significantly only decreased per capita consumption. Yet, in the short-run, trade liberalization has a positive and significant effect on per capita consumption and life expectancy. In contrast, it has a negative and significant impact on the infant mortality rate. From these findings, it can be said that in Mali, the effect of trade liberalization on poverty reduction is not sensitive to poverty proxies but depends on complementary policies. Factors such as financial deepening, education, consumer price index institutional quality, and infrastructure development seem to influence the relationship between trade liberalization, and poverty reduction.
\end{abstract}

Keywords: trade liberalization, poverty reduction, ARDL, Mali

\section{Introduction}

Considered as the best policy to achieve rapid growth since the 1980s, the impact of trade liberalization on poverty reduction is today one of the most controversial topics among policymakers and researchers. While trade liberalization has benefited some states, the same can not be said to many others, particularly those of Africa. China, for example, is cited as an example because it has been able to reduce poverty through openness. For instance, from 1990 to 2016, the country's trade share of GDP rose from 24.27 per cent to 38.24 per cent. In the same period, GDP grew at more than 9 per cent a year, and poverty (USD1.9) decreased dramatically from 66.2 per cent to 0.5 per cent.

In contrast, despite a remarkable increase in trade of goods and services in Mali, poverty is still widespread. Over 43 per cent of the population lives with less than USD 1.95 a day in 2014. Life expectancy at birth remains low (55 years), and the infant mortality rate high (62 deaths per 1000 live births) in 2018. This implies that there is no automatic linkage between trade liberalization, and poverty reduction and that trade reform can generate both winners and losers.

The literature has provided a few studies on the relationship between trade liberalization and poverty reduction in Mali. Moreover, most of them were based on cross countries studies such as Sub-Saharan Africa (SSA), Least Developed Countries (LDC), Landlocked Least Developed Countries (LLDC) or developing countries, and they provided mixed results. While Novignon (2018), Anetor et al. (2020) found that trade decrease poverty, Onakoya et al. (2019) found that it increases the level of poverty. Furthermore, Le Goff and Singh (2014) using data for the period 1981 to 2010 showed that the benefit of trade liberalization in a country like Mali could be low or negative because of lack of complementary policy( such as low level of financial development, low level of education, and poor institutions).

It is apparent that, despite these empirical studies, there is no consensus in the case of Mali. Therefore, there is necessary to fill this research gap by investigating the link between trade liberalization and poverty reduction in Mali.

The rest of this study is organized in the following manner. Section two reviews the literature on the relationship 
between trade liberalization and poverty reduction. Section three presents the methodology. Section four presents the empirical findings. Finally, the conclusion and some policy recommendations are provided in section five.

\section{Literature Reviews}

\subsection{Theoretical Literature}

According to the analytical framework developed by Winter $(2000,2004)$, there are theoretically four channels through which trade liberalization can affect poverty reduction.

- The first one is economic growth. For the proponent of this channel, openness to trade leads to long term economic growth which in turn reduces poverty. If researchers widely accept economic growth as the key to sustained poverty alleviation, there is still debate among them on the relationship between trade liberalization and economic growth. Some authors have demonstrated that trade promotes growth by increasing the size of the market, facilitating access to cheaper imported goods and knowledge available in the world. It can also enhance growth by allocating more resources to the Research and Development (R\&D) or human and physical capital sectors (Grossman \& Helpman, 1990; Lucas, 1988; Rebelo, 1991; Rivera-Batiz \& Romer, 1991; Grossman \& Helpman, 1990, 1991a; Feenstra, 1996 ). In contrast to them, others showed that the positive impact of trade on growth depends on the country's development level or complementary policies (Calderon et al., 2004 and Daumon \& Ozyiurt, 2011). Also, Young (1997) and Bourdon and Vijil (2013) showed that trade reduces growth in the country specialized in the production and export of low technology, low quality, or few products.

- The second channel is the change in the price of goods and services. But the effect depends on the fact that the poor households are net producers or net consumers. The price increase of goods and services will positively affect net producers and harm net consumers. Whereas, a decrease in the price of goods and services will benefit net consumers and harm net producers.

- The third one is the wage and employment channels. This channel is based on the Heckscher-Ohlin theorem, which suggests that trade liberalization by increasing the employment and wage of unskilled labour will reduce poverty in developing countries. However, if this theorem is very powerful in theory, Winters (2004) argued that in practice, many other factors might need to be considered. For instance, openness to trade may be accompanied by skilled biased technical changes which generally increase the demand for skilled labour relative to unskilled labour. Thus, in that case, poverty will be unaffected or worsened by trade liberalization.

- Finally, the fourth channel is government revenue and spending. Following Sharer et al. (1998), trade liberalization can positively or negatively affect government revenue. On the one hand, tariffs reduction or elimination from trade liberalization will lower the revenue of the government. And this reduction will, in turn, lower public spending on social activities( such as health, education, infrastructure) which disproportionately affect the poor. But, on the other hand, trade liberalization will increase government revenue. For instance, by reducing the incentive for smuggling and corruption, lower tariffs can increase the volume of goods recorded at customs which in turn boost government revenue.

\subsection{Empirical Literature}

The empirical studies on the link between trade liberalization and poverty( monetary and non-monetary) in the case of Africa have yielded mixed results. While some researchers found that openness to trade has a positive effect on poverty reduction, others showed the effect negative or even insignificant. In this study, we will review some of them.

Saibu et al. (2012) employed the vector error correction method to examine the relationship between trade openness, unemployment, and poverty in Nigeria for the period 1986-2010. The results indicate that trade openness has a significant positive on economic growth and unemployment but a significant negative impact on poverty in the long run.

Le Goff and Singh (2014) used the GMM estimator examined the effect of trade openness on poverty reduction in 30 African countries over the period 1981-2010. They found that trade openness reduces poverty in the country with a high level of financial intermediation, high literacy rate, and strong institution.

In the case of Zimbabwe, Musvovi (2014) used an Ordinary Least Square (OLS) method to determine the effect of trade on poverty reduction from 1986 to 2012. The findings indicate that trade liberalization has a positive impact on poverty in Zimbabwe.

Kelbore (2015) also employed a GMM estimator to examine the effect of trade openness and structural transformation on poverty in 43 African countries during the period 1881-2010. He found that trade openness initially increases poverty by 1.3 percent and reduces it by about 1.2 percent after one-period lags. Further, GDP 
per capita, domestic credit to the private sector, and infrastructure are found to harm poor people.

Besong (2016) used VECM methodology yo examine the relationship between financial sector development, income inequality, and human welfare (proxy by HDI and under-five infant mortality) in 29 Sub-Saharan African countries from 1990 to 2010. He found an insignificant impact of trade openness on under-five infant mortality

Nyarkoh (2017) employed the Vector error correction model test, and the ordinary least square (OLS) to examine the effect of trade openness on poverty in Ghana for the period 1960-2013. He found that trade liberalization was negatively related to poverty in Ghana in the short-run and long-run. Bright (2017) also using the OLS technique, confirmed these results and found the negative relationship between poverty incidence and trade liberalization in both the long-run and short-run.

Novignon et al. (2018) used three estimation models (fixed effect, random effect, and GMM) to investigate the impact of trade openness on population health proxies by life expectancy, infant mortality rate, and under-five mortality rate in 42 countries in Sub-Saharan African from 1995-2013. They found a positive and significant relationship between trade openness and life expectancy and a negative and significant relationship between trade openness and both infant mortality rate and the under-five mortality rate.

Jawadi et al. (2018) employed panel data to examine the effect of health outcomes from trade openness in 12 countries in the MENA region from 1970 to 2015. They found that openness to trade reduces infant mortality rate and increases expectancy for both men and women in the region.

Onakoya et al. (2019) investigated the link between trade liberalization and poverty in 21 African countries from 2005 to 2014. Using both the pooled OLS technique and the panel cointegration test, they found a negative and significant relationship between trade openness and poverty. Contrary to them, Anetor et al. (2020) using the feasible generalized least square explored the relationship between international flows (foreign direct investment, foreign aid, and foreign trade) and poverty reduction in 29 Sub-Saharan African countries. The findings reveal a positive and significant link between foreign trade and poverty reduction.

\section{Method}

\subsection{ARDL Bounds Test to Cointegration}

Following Odhiambo and Magombeyi (2017), the ARDL bounds test cointegration developed by Pesaran et al. (2001) will be employ in this study. This approach is chosen because of several reasons. First, the ARDL bounds test, as opposed to the Johansen and Juselius cointegration, is simple and allows a cointegrating relationship to be estimated by OLS once the lag order is selected. Secondly, it does not require all the variables to be integrated of the same order of integration I(1), unlike VAR/VECM approaches. Variables can be integrated of order one I(1) or I(0). Third, it is relatively more efficient in small sample data sizes, as is the case of our study. Fourth, the error correction method integrates the short-run dynamics with long-run equilibrium without losing long-run information.

\subsection{Model Specification}

This study will use three measures of poverty reduction in order to capture the effect of trade liberalization on both monetary and non-monetary poverty. We will employ three models. Model 1 examines the impact of trade liberalization on per capita consumption. Model 2 examines the impact of trade liberalization on infant mortality rate. And model 3 examines the impact of trade liberalization on life expectancy. Therefore, following Le Goff and Singh (2014), the three models will be specified as follow: Therefore, following Le Goff and Singh (2014), the three models will be specified as follow:

Model 1:

$$
P C C=\beta_{0}+\beta_{1} O P E N+\beta_{2} P G D P+\beta_{3} F D I+\beta_{4} F D+\beta_{5} E D U+\beta_{6} C P I+\beta_{7} I N F R+\beta_{8} I Q+\varepsilon_{t}
$$

Model 2:

$$
I M R=\beta_{0}+\beta_{1} O P E N+\beta_{2} P G D P+\beta_{3} F D I+\beta_{4} F D+\beta_{5} E D U+\beta_{6} C P I+\beta_{7} I N F R+\beta_{8} I Q+\varepsilon_{t}
$$

Model 3:

$$
L E=\beta_{0}+\beta_{1} O P E N+\beta_{2} P G D P+\beta_{3} F D I+\beta_{4} F D+\beta_{5} E D U+\beta_{6} C P I+\beta_{7} I N F R+\beta_{8} I Q+\varepsilon_{t}
$$

Where, PCC is per capita consumption, IMR is infant mortality rate, LE is life expectancy, OPEN is trade openness, PGDP is per capita GDP, FDI is foreign direct investment, FD is financial deepening, EDU is education proxied by gross secondary school enrollment, CPI is consumer price index, INFR is infrastructure development proxied by road paved and IQ is institutional quality proxies by the summation of nine PRS indicators, including corruption, bureaucracy quality, rule of law, government stability, external conflict, internal 
conflict, investment profile, military in politics, and democratic accountability.

The non-linear function specified above can be easily estimated by converting equations 1,2 and 3 into a linear regression after taking the logarithm of both sides of the function as stated in equation 4,5 , and 6 . We obtain:

Model 1:

$L P C C=\beta_{0}+\beta_{1} L O P E N+\beta_{2} L P G D P+\beta_{3} L F D I+\beta_{4} L F D+\beta_{5} L E D U+\beta_{6} L C P I+\beta_{7} L I N F R+\beta_{8} L I Q+\varepsilon_{t}$

Model 2:

$L I M R=\beta_{0}+\beta_{1} L O P E N+\beta_{2} L P G D P+\beta_{3} L F D I+\beta_{4} L F D+\beta_{5} L E D U+\beta_{6} L C P I+\beta_{7} L I N F R+\beta_{8} L I Q+\varepsilon_{t}$

Model 3:

$$
L L E=\beta_{0}+\beta_{1} L O P E N+\beta_{2} L P G D P+\beta_{3} L F D I+\beta_{4} L F D+\beta_{5} L E D U+\beta_{6} L C P I+\beta_{7} L I N F R+\beta_{8} L I Q+\varepsilon_{t}
$$

The ARDL model and the error correction specification are given in equations 7, 8 , and 9 for model 1 , model 2 , and model 3 respectively.

\section{Model 1: ARDL specification}

$$
\begin{gathered}
\triangle L P C C_{t}=\alpha_{0}+\sum_{i=0}^{n} \alpha_{1} \Delta L P C C_{t-I}+\sum_{i=0}^{n} \alpha_{2} \Delta L O P E N_{t-i}+\sum_{i=0}^{n} \alpha_{3} \Delta L P G D P_{t-i}+\sum_{i=0}^{n} \alpha_{4} \Delta L F D I_{t-1}+ \\
\sum_{i=0}^{n} \alpha_{5} \Delta L F D_{t-I}+\sum_{i=0}^{n} \alpha_{6} \Delta L E D U_{t-I}+\sum_{i=0}^{n} \alpha_{7} \Delta L C P I_{t-1}+\sum_{i=0}^{n} \alpha_{8} \Delta L I N F R_{t-I}+\sum_{i=0}^{n} \alpha_{9} \Delta L I Q_{t-i}+ \\
\vartheta_{1} L P C C_{t-1}+\vartheta_{2} L O P E N_{t-1}+\vartheta_{3} L P G D P_{t-1}+\vartheta_{4} L F D I_{t-1}+\vartheta_{5} L F D_{t-1}+\vartheta_{6} L E D U_{t-1}+\vartheta_{7} L C P I_{t-1}+ \\
\vartheta_{8} L I N F R_{t-1}+\vartheta_{9} L I Q_{t-1}+\mu_{1 t}
\end{gathered}
$$

Where $\alpha_{1}-\alpha_{9}$ and $\vartheta_{1}-\vartheta_{9}$ are regression coefficients, $\alpha_{0}$ is a constant and, $\mu_{1 \mathrm{t}}$ is white noise error term.

The error correction model for Model 1 is specified as follows:

$$
\begin{gathered}
\Delta L P C C_{t}=\alpha_{0}+\sum_{i=0}^{n} \alpha_{1} \Delta L P C C_{t-i}+\sum_{i=0}^{n} \alpha_{2} \Delta L O P E N_{t-i}+\sum_{i=0}^{n} \alpha_{3} \Delta L P G D P_{t-i}+\sum_{i=0}^{n} \alpha_{4} \Delta L F D I_{t-i}+ \\
\sum_{i=0}^{n} \alpha_{5} \Delta L F D_{t-i}+\sum_{i=0}^{n} \alpha_{6} \Delta L E D U_{t-i}+\sum_{i=0}^{n} \alpha_{7} \Delta L C P I_{t-i}+\sum_{i=0}^{n} \alpha_{8} \Delta L I N F R_{t-i}+\sum_{i=0}^{n} \alpha_{9} \Delta L I Q_{t-i}+ \\
\gamma_{1} E C M_{t-1}+\mu_{t}
\end{gathered}
$$

Where $\alpha_{1}-\alpha_{9}$ and $\gamma_{1}$ are coefficients, $\alpha_{0}$ is a constant, $\mathrm{ECM}_{\mathrm{t}-1}$ is lagged error term and $\mu_{\mathrm{t}}$ is white noise error term.

\section{Model 2: ARDL specification}

$$
\begin{aligned}
& \Delta L I M R_{t}=\alpha_{0}+\sum_{i=0}^{n} \alpha_{1} \Delta L I M R_{t-I}+\sum_{i=0}^{n} \alpha_{2} \Delta \text { LOPEN }_{t-i}+\sum_{i=0}^{n} \alpha_{3} \Delta L P G D P_{t-i}+\sum_{i=0}^{n} \alpha_{4} \Delta L F D I_{t-I}+ \\
& \sum_{i=0}^{n} \alpha_{5} \Delta L F D_{t-I}+\sum_{i=0}^{n} \alpha_{6} \Delta L E D U_{t-I}+\sum_{i=0}^{n} \alpha_{7} \Delta L C P I_{t-I}+\sum_{i=0}^{n} \alpha_{8} \Delta L I N F R_{t-I}+\sum_{i=0}^{n} \alpha_{9} \Delta L I Q_{t-i}+ \\
& \vartheta_{1} L_{I M R_{t-1}}+\vartheta_{2} \text { LOPEN }_{t-1}+\vartheta_{3} L P G D P_{t-1}+\vartheta_{4} L F D I_{t-1}+\vartheta_{5} L F D_{t-1}+\vartheta_{6} L E D U_{t-1}+\vartheta_{7} L C P I_{t-1}+ \\
& \vartheta_{8} L I N F R_{t-1}+\vartheta_{9} L I Q_{t-1}+\mu_{1 t}
\end{aligned}
$$

Where $\alpha_{1}-\alpha_{9}$ and $\vartheta_{1}-\vartheta_{9}$ are regression coefficients, $\alpha_{0}$ is a constant and, $\mu_{1 \mathrm{t}}$ is white noise error term.

The error correction model for Model 1 is specified as follows:

$$
\begin{gathered}
\Delta L I M R_{t}=\alpha_{0}+\sum_{i=0}^{n} \alpha_{1} \Delta L I M R_{t-i}+\sum_{i=0}^{n} \alpha_{2} \Delta L O P E N_{t-i}+\sum_{i=0}^{n} \alpha_{3} \Delta L P G D P_{t-i}+\sum_{i=0}^{n} \alpha_{4} \Delta L F D I_{t-i}+ \\
\sum_{i=0}^{n} \alpha_{5} \Delta L F D_{t-i}+\sum_{i=0}^{n} \alpha_{6} \Delta L E D U_{t-i}+\sum_{i=0}^{n} \alpha_{7} \Delta L C P I_{t-i}+\sum_{i=0}^{n} \alpha_{8} \Delta L I N F R_{t-i}+ \\
\sum_{i=0}^{n} \alpha_{9} \Delta L I Q_{t-i}+\gamma_{1} E C M_{t-1}+\mu_{t}
\end{gathered}
$$

Where $\alpha_{1}-\alpha_{9}$ and $\gamma_{1}$ are coefficients, $\alpha_{0}$ is a constant, $\mathrm{ECM}_{\mathrm{t}-1}$ is lagged error term and $\mu_{\mathrm{t}}$ is white noise error term.

\section{Model 3: ARDL specification}

$$
\begin{gathered}
\Delta L L E_{t}=\alpha_{0}+\sum_{i=0}^{n} \alpha_{1} \Delta L L E_{t-I}+\sum_{i=0}^{n} \alpha_{2} \Delta L O P E N_{t-i}+\sum_{i=0}^{n} \alpha_{3} \Delta L P G D P_{t-i}+\sum_{i=0}^{n} \alpha_{4} \Delta L F D I_{t-I}+ \\
\sum_{i=0}^{n} \alpha_{5} \Delta L F D_{t-1}+\sum_{i=0}^{n} \alpha_{6} \Delta L E D U_{t-I}+\sum_{i=0}^{n} \alpha_{7} \Delta L C P I_{t-1}+\sum_{i=0}^{n} \alpha_{8} \Delta L I N F R_{t-I}+\sum_{i=0}^{n} \alpha_{9} \Delta L I Q_{t-i}+ \\
\vartheta_{1} L L E_{t-1}+\vartheta_{2} L O P E N_{t-1}+\vartheta_{3} L P G D P_{t-1}+\vartheta_{4} L F D I_{t-1}+\vartheta_{5} L F D_{t-1}+\vartheta_{6} L E D U_{t-1}+\vartheta_{7} L C P I_{t-1}+ \\
\vartheta_{8} L_{I N F R_{t-1}}+\vartheta_{9} L I Q_{t-1}+\mu_{1 t}
\end{gathered}
$$

Where $\alpha_{1}-\alpha_{9}$ and $\vartheta_{1}-\vartheta_{9}$ are regression coefficients, $\alpha_{0}$ is a constant and, $\mu_{1 \mathrm{t}}$ is white noise error term.

The error correction model for Model 1 is specified as follows:

$$
\begin{gathered}
\Delta L L E_{t}=\alpha_{0}+\sum_{i=0}^{n} \alpha_{1} \Delta L L E_{t-i}+\sum_{i=0}^{n} \alpha_{2} \Delta L O P E N_{t-i}+\sum_{i=0}^{n} \alpha_{3} \Delta L P G D P_{t-i}+\sum_{i=0}^{n} \alpha_{4} \Delta L F D I_{t-i}+ \\
\sum_{i=0}^{n} \alpha_{5} \Delta L F D_{t-i}+\sum_{i=0}^{n} \alpha_{6} \Delta L E D U_{t-i}+\sum_{i=0}^{n} \alpha_{7} \Delta L C P I_{t-i}+\sum_{i=0}^{n} \alpha_{8} \Delta L I N F R_{t-i}+ \\
\sum_{i=0}^{n} \alpha_{9} \Delta L I Q_{t-i}+\gamma_{1} E C M_{t-1}+\mu_{t}
\end{gathered}
$$

Where $\alpha_{1}-\alpha_{9}$ and $\gamma_{1}$ are coefficients, $\alpha_{0}$ is a constant, $\mathrm{ECM}_{\mathrm{t}-1}$ is lagged error term and $\mu_{\mathrm{t}}$ is white noise error term. 


\subsection{Data Sources}

This study used annual data covering the period 1986 to 2018. All the variables were expressed in natural logarithm. Data on per capita consumption, per capita GDP, financial deepening, gross secondary school enrollment were obtained from World Bank Development Indicators. Foreign direct investment inflows, consumer price index and trade openness data were obtained from the United Nations Conference on Trade and Development (UNCTAD) statistics database. The data of Institutional quality is obtained from the International Country Risk Guide. Lastly data on roads paved, infant mortality rate and life expectancy were obtained from African Development Indicators Database.

\section{Empirical Results}

\subsection{Stationarity Tests}

Before we conduct a test for co-integration, we have to make sure that all the variables under consideration are not integrated at an order higher than one. Thus, to test the integration properties of the series, we have used Augmented Dickey-Fuller(ADF) and Phillips Perron(PP) unit root tests. Table 1 below present the results of the stationarity test. From the table, we can see that all the variables are non-stationary at level, which means that all of them contain a unit root. This can be seen by comparing the P-value of both ADF and PP test statistic with 1 per cent, 5 per cent, and 10 per cent level of significance. However, they become stationary at first difference. Thus, we can conclude that all the variables are integrated of order one I (1), which confirms the suitability of the ARDL-based analysis.

Table 1. Unit root test results

\begin{tabular}{|c|c|c|c|c|c|c|c|c|}
\hline \multirow[b]{3}{*}{ Variables } & \multicolumn{4}{|c|}{ ADF Test } & \multicolumn{4}{|c|}{ PP Test } \\
\hline & \multicolumn{2}{|c|}{ Stationary at Level } & \multicolumn{2}{|c|}{ Stationary at First Difference } & \multicolumn{2}{|c|}{ Stationary at Level } & \multicolumn{2}{|c|}{ Stationary at First Difference } \\
\hline & Without Trend & With Trend & Without Trend & With Trend & Without Trend & With Trend & Without Trend & With Trend \\
\hline LPCC & -0.57 & -2.99 & $-9.97 * * *$ & $-10.04 * * *$ & 0.07 & -2.99 & $-10.59 * * *$ & $-11.74 * * *$ \\
\hline LIMR & -1.64 & -1.22 & $-5.74 * * *$ & $-5.98 * * *$ & -1.64 & -1.22 & $-5.74 * * *$ & $-5.98 * * *$ \\
\hline LLEB & 1.29 & $-5.22 * * *$ & $-4.42 * * *$ & $-4.36^{* *}$ & -1.87 & $-5.22 * * *$ & $-24.53 * * *$ & $-24.13 * * *$ \\
\hline LOPEN & -2.19 & -3.18 & $-7.72 * * *$ & $-7.59 * * *$ & -2.03 & -3.14 & $-9.69 * * *$ & $-10.74 * * *$ \\
\hline LFDI & -1.85 & -2.84 & $-5.80 * * *$ & $-5.73 * * *$ & -1.67 & -2.69 & $-7.56 * * *$ & $-8.31 * * *$ \\
\hline LPGDP & -0.57 & $-4.39^{* *}$ & $-8.72 * * *$ & $-8.58 * * *$ & -0.39 & -2.44 & $-8.59 * * *$ & $-8.46^{* * *}$ \\
\hline LFD & -1.03 & -2.63 & $-7.00^{* * *}$ & $-7.09 * * *$ & -0.68 & -2.51 & $-7.26^{* * * *}$ & $-9.01 * * *$ \\
\hline LEDU & -1.34 & 0.24 & $-5.04 * * *$ & $-5.19 * * *$ & -1.16 & -0.34 & $-5.37 * * *$ & $-5.43 * * *$ \\
\hline LCPI & -0.91 & -2.54 & $-4.14 * * *$ & $-4.12^{* * *}$ & -0.91 & -1.99 & $-3.95 * * *$ & $-3.98 * *$ \\
\hline LINFR & -068 & -2.13 & $-5.62 * * *$ & $-5.52 * * *$ & -0.59 & -2.24 & $-5.70 * * *$ & $-5.59 * * *$ \\
\hline LIQ & -2.03 & -1.59 & $-4.92 * * *$ & $-5.28 * * *$ & -2.16 & -1.29 & $-4.93 * * *$ & $-5.28 * * *$ \\
\hline
\end{tabular}

Note. *,** and *** show the significance at respectively $10 \%, 5 \%$ and $1 \%$ level. $\mathrm{L}$ is natural logarithm. The software E-views 10 was used for these tests.

\subsection{Bound Testing Approach to Co-Integration}

After establishing that all the variables are integrated of order one $\mathrm{I}(1)$, the next step is to employ the ARDL approach to cointegration in order to determine the long-run relationship among trade liberalization, economic growth, foreign direct investment, financial deepening, education, consumer price index, infrastructure development, institutional quality and poverty reduction (per capita consumption, infant mortality rate, life expectancy). The results reported that the calculated F-statistics is greater than the critical values at $10 \%, 5 \%$ and $1 \%$ for all poverty measures.

Table 2. Cointegration results and critical values

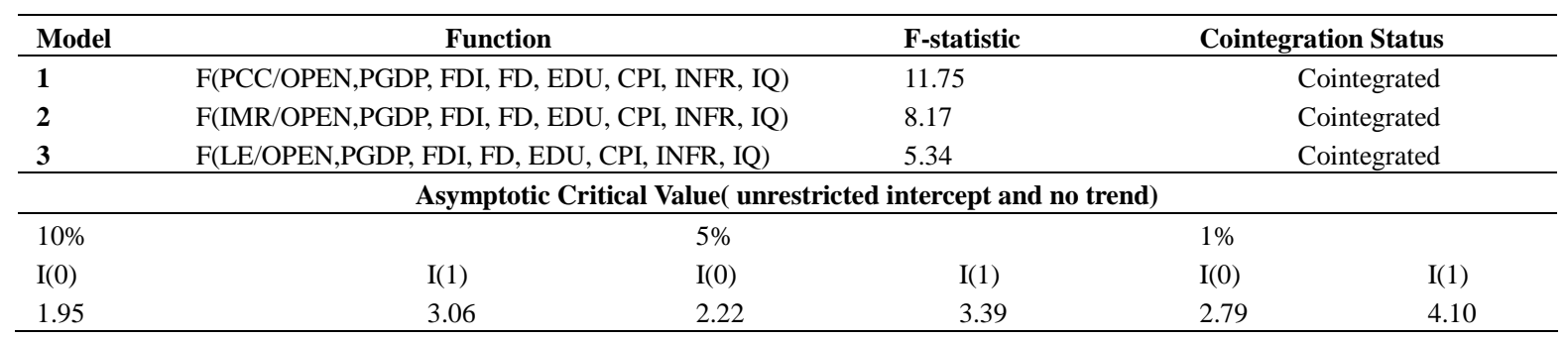

Note. The software E-views 10 was used for these tests. 


\subsection{Long-Run and Short-Run Impact of Trade Liberalization on Poverty Reduction}

Table 3. Long-run and short-run estimates

\begin{tabular}{|c|c|c|c|c|c|c|}
\hline \multicolumn{7}{|l|}{ Long-Run Coefficient } \\
\hline \multirow{2}{*}{$\begin{array}{l}\text { Model } \\
\text { Regressor }\end{array}$} & \multicolumn{2}{|c|}{ Model 1(LPCC) } & \multicolumn{2}{|c|}{ Model 2(LIMR) } & \multicolumn{2}{|c|}{ Model 3(LLE) } \\
\hline & Coefficient & T-stat & Coefficient & T-stat & Coefficient & T-stat \\
\hline LOPEN & $-0.2771^{*}$ & -1.9151 & -0.0711 & -0.7735 & -0.0113 & -0.3551 \\
\hline LFDI & $-0.0206 * * *$ & -3.5159 & $0.0253 *$ & 2.0325 & -0.0005 & -0.1719 \\
\hline LPGDP & $1.0454 * *$ & 2.4872 & $-0.5103^{* *}$ & -2.6738 & $0.2271^{* *}$ & 3.1599 \\
\hline LEDU & -0.2268 & -1.1657 & -0.0705 & -0.9096 & $0.0911 * *$ & 2.9774 \\
\hline LFD & 0.1229 & 1.7634 & 0.0410 & 0.9096 & 0.0371 & 1.3469 \\
\hline LCPI & $0.7639^{*}$ & 2.1643 & -0.4141 & -2.3723 & -0.0101 & -0.1444 \\
\hline LINFR & 0.0691 & 0.8672 & $-0.1396^{* * *}$ & -2.4761 & -1.5600 & -0.0008 \\
\hline LIQ & $-0.6419 * * *$ & -4.8755 & $0.2272 * * *$ & 3.4509 & $-0.1031 * * *$ & -6.4695 \\
\hline \multicolumn{7}{|l|}{ Short-Run Coefficient } \\
\hline Constant & -0.9671 & & 4.7749 & & 1.5742 & \\
\hline DLOPEN & -0.0154 & -0.4832 & $-0.0549 * *$ & -3.3471 & $0.0184 * *$ & 3.2497 \\
\hline DLOPEN(-1) & $0.1049 * *$ & 2.9501 & $-0.0708^{* * *}$ & -4.7049 & $0.0248 * * *$ & 4.3723 \\
\hline DLFDI & $0.0039 * * *$ & 5.5629 & $0.0040 * * *$ & 3.9403 & $0.0008^{* *}$ & 1.9349 \\
\hline DLFDI(-1) & & & $-0.0081^{* * *}$ & -6.4842 & -0.0011 & -1.8684 \\
\hline DLPGDP & $1.2289 * * *$ & 19.2014 & -0.0173 & -0.5446 & $0.0725 * * *$ & 4.7859 \\
\hline $\operatorname{DLPGDP}(-1)$ & & & & & $-0.0484^{* *}$ & -3.3512 \\
\hline DLEDU & $0.5288^{* * *}$ & 8.2889 & $-0.0400^{* *}$ & -2.4624 & $0.0356^{* * *}$ & 4.6236 \\
\hline DLEDU(-1) & $0.6077 * * *$ & 11.8934 & $0.0507 * *$ & 2.8819 & & \\
\hline DLFD & $0.0874 * *$ & 2.9103 & 0.0118 & 1.3427 & $0.0339 * * *$ & 5.4283 \\
\hline DLFD(-1) & $0.1408^{* * *}$ & 6.9123 & $-0.0264^{* *}$ & -3.3544 & $0.0154 * * *$ & 4.6236 \\
\hline DLCPI & $0.5511 * * *$ & 5.7195 & $-0.0797 * *$ & -2.3158 & $0.0719 * * *$ & 3.8122 \\
\hline DLCPI(-1) & $0.4156^{* * *}$ & 6.2023 & & & $0.0746^{* * *}$ & 6.0104 \\
\hline DLINFR & 0.0157 & 0.7926 & -0.0109 & -1.3354 & $0.0110 * *$ & 2.7239 \\
\hline \multicolumn{7}{|l|}{ DLINFR(-1) } \\
\hline DLIQ & $-0.6072 * * *$ & -12.5752 & -0.0124 & -0.9464 & -0.0046 & -0.7582 \\
\hline DLIQ(-1) & $0.2577 * * *$ & 6.3969 & $-0.0878 * * *$ & -5.0595 & $0.0508 * * *$ & 6.7399 \\
\hline $\operatorname{ECM}(-1)$ & $-0.7061 * * *$ & -14.5454 & $-0.4955^{* * * *}$ & -12.1283 & $-0.6631 * * *$ & -10.5929 \\
\hline R-Squared & \multicolumn{2}{|c|}{0.9755} & \multicolumn{2}{|c|}{0.9389} & \multicolumn{2}{|c|}{0.9486} \\
\hline Adjusted R-squared & \multicolumn{2}{|c|}{0.9541} & \multicolumn{2}{|c|}{0.8855} & \multicolumn{2}{|c|}{0.8897} \\
\hline DW Stat & \multicolumn{2}{|c|}{2.7078} & \multicolumn{2}{|c|}{2.4558} & \multicolumn{2}{|c|}{2.3996} \\
\hline F-Statistics & \multicolumn{2}{|c|}{$45.5908[0.000]$} & \multicolumn{2}{|c|}{$17.5716[0.000]$} & \multicolumn{2}{|c|}{$16.1348[0.000]$} \\
\hline Serial Correlation & \multicolumn{2}{|c|}{$4.2786[0.0700]$} & \multicolumn{2}{|c|}{$4.0697[0.0764]$} & \multicolumn{2}{|c|}{$5.4069[0.0729]$} \\
\hline Heteroscedasticity & \multicolumn{2}{|c|}{$0.6919[0.7665]$} & \multicolumn{2}{|c|}{$0.8524[0.6418]$} & \multicolumn{2}{|c|}{$2.2714[0.1555]$} \\
\hline J-B Normality Test & \multicolumn{2}{|c|}{$0.2443[0.8850]$} & \multicolumn{2}{|c|}{$3.0693[0.2155]$} & 0.4152 & 25] \\
\hline
\end{tabular}

Note. ${ }^{*}, * *$ and $* * *$ show the significance at respectively $10 \%, 5 \%$ and $1 \%$ level.The software E-views 10 was used for these tests.

4.3.1 Discussion of the Empirical Results on the Relationship between Trade Liberalization and Per Capita Consumption

The results presented in Table 3 for model 1 show that the coefficient of trade openness is negative in both the long run and short run but statistically significant only in the long run. According to the result, a 1 per cent rise in trade openness decrease per capita consumption( or increase the poverty level) by 0.27 per cent in the long run while it does not influence per capita consumption in the short run. The long-run result is contrary to expected sign and finding of Giles and Williams (2000), who show that an increase in trade can increase exports, which come with increased incomes and hence higher consumption. However, it is in line with the findings of Magombeyi and Odhiambo (2017), Onakoya et al. (2019). The negative relationship could be due to several reasons. The first one is the low level of financial intermediation, low level of education, and poor institutional quality. Lee Goff and Singh (2013) demonstrated that openness to international trade could not reduce poverty in countries with low access to credit, low level of education, and also lack of governance. The second reason for the negative relationship could be due to the export structure of Mali, which remained unchanged and highly concentrated on three primary commodities. This makes the country vulnerable to world price volatility and weather conditions. According to Hewit (2003), commodities price instability hurts economic growth and lead to 
increase poverty. The short-run result is consistent with the findings of several studies in the literature (see Akmal et al., 2007; Chaudhry \& Imram, 2013; Agasalim, 2017). The explanation of that in the case of Mali is because the majority of poor people in Mali are not directly linked to the country's export products (gold and cotton). For instance, if some poor peoples produce cotton in Mali, most of them are producers of products such as rice, millet, and sorghum.

With regards to the control variables, (i) economic growth has a positive and significant impact on per capita consumption in the long-run and short run. This suggests that an increase in economic growth by one percent increase per capita consumption (or decrease poverty levels) by 1.04 percent in the long-run and 1.22 percent in the short-run. Thus, this result was in line with the expected sign and consistent with the absolute hypothesis, which indicates that the increase in income will increase consumer spending. (ii) The coefficient of FDI is negative and statistically significant in the long-run, while positive and significant in the short-run. (iii) The coefficient of financial deepening proxy by domestic credit to the private sector is insignificant in the long run, while it is positive and statistically significant in the short run. This suggests that an increase in financial deepening does not affect per capita consumption in the long run, but increase it by 0.08 percent in the short run. (iv) The coefficient of education (proxy by gross secondary school enrollment) is negative and statistically insignificant in the long run, while a positive relationship with per capita consumption is confirmed in the short run. This suggests that an increase in education does not play a significant role in reducing poverty in Mali in the long run but increases it by 0.52 percent in the short run. (v) The coefficient of CPI is found to have a positive impact on per capita consumption in the long- and short-run. A one percent increase in consumer price index leads to a 0.76 percent and 0.55 percent increase in per capita consumption, respectively, in the long and short run. (vi) The coefficient of infrastructure development captured by a road paved is positive but statistically insignificant both the long run and short run. This suggests that infrastructure development does not play a significant role in poverty reduction in Mali. (vii) The coefficient of institutional quality is negative and statistically significant in both the long-run and short-run. At the same time, a statistically positive relationship was confirmed at lag one in the short run. (viii) The coefficient value of ECM is negative and statistically significant at 1 percent level of significance which implies that the results support the existence of a long-run association between all the variables used in this study. It also suggests that approximately 70 percent of the short-run disequilibrium is corrected in the long run.

According to the robustness, the coefficient of R-squared value is 0.97 , which implies that the independent variables jointly account for about 97 percent of the total variation in per capita consumption. Subsequently, the remain 3 percent may be due to other factors such as unstable rainfall.The adjusted coefficient of determination (R2) value of 0.95 implies that per cent of the total variation in per capita consumption is explained by the change in the endogenous variables when the coefficient of determination is adjusted for the degree of freedom. The F-statistic value of 45.59 is statistically significant at 5 percent level of significance which implies that the model is a good fit. The Durbin- Watson statistic value of 2.70 indicates the absence of auto-correlation in the estimated model. The diagnostic test results conclude that there is no serial correlation, heteroscedasticity, and anomaly. This implies that the model has no problem.

4.3.2 Discussion of the Empirical Results on the Relationship between Trade liberalization and Infant Mortality Rate

The results presented in Table 3 for model 2 show that trade openness is negative in both the long-run and short-run but statistically significant only in the short-run. This implies that an increase in trade openness does not influence infant mortality rate in the long run, but significantly reduce it by 0.05 percent in the short-run. The long-run result is contrary to expected signs and findings of some economists (see Herzer, 2017; Novignon et al., 2018), while consistent with the findings of Magombeyi and Odhiambo (2017), and Barlow (2018). This may be due to the fact most of the poor people are not directly linked to Mali merchandise exports. For instance, the production and export of Gold, which is the main export goods of Mali (66 percent of total merchandise exports on average), have created a formal job for skilled labor who generally come from the urban area. However, the explanation of the short-run result may be access to medical goods because of trade openness. According to Papageorgiou et al. (2007), medical products imported from countries that are major exporters of medical technology are positively correlated with the health status in countries that do not perform pharmaceutical R\&D. In the case of Mali, access to imports goods such as impregnated mosquito nets has reduced the number of confirmed cases of malaria(a leading cause of infant death and pregnant women) over the past decade.

With regards to the control variables, (i) economic growth proxied by per capita GDP is negative both in the long run and short run, but it is statistically significant at 5 per cent only in the long-run. This implies that an increase in GDP per capita has reduced infant mortality by 0.51 per cent in the long run, while its impact has been 
insignificant in the short-run. (ii) FDI is positive and statistically significant in both the long run and short run. However, the negative and significant relationship exists between foreign direct investment and infant mortality rate in the short-run at lag one. The outcome suggests that an increase in foreign direct investment tends to increase infant mortality rate by 0.025 percent and 0.004 percent in the long-run and short-run while decreasing infant mortality in the short run lag one by 0.008 percent. (iii) financial deepening is positive and insignificant in both the long run and short run. At the same time, at lag one in the short-run, it has a negative and significant relationship with the infant mortality rate. This suggests that the financial deepening does not any significant impact on infant mortality in Mali in the long run as well as the short run, whereas it reduces infant mortality rate in the short term at lag one. (iv) education has a negative association with the infant mortality rate in both the long run and short run, but its impact is statistically significant only in the short run. However, it has a positive impact on the infant mortality rate in lag one in the short run. This suggests that an increase in education does not play a significant role in infant mortality rate in Mali in the long-run, but reduces it by 0.04 per cent in short-run. (v) Consumer price index which is used as a proxy of inflation in this study is found to have a negative relationship with the infant mortality rate in both the long-run and short-run, while their link is significant only in the short run. This result suggests that an increase in inflation does not statistically affect infant mortality rate in the long-run but significantly reduces it by 0.07 per cent in the short-run. (vi) Infrastructure development captured by a road paved is negative in both the long run and short run, while statistically significant only in the long term. An increase in infrastructure development by 1 percent would decrease the infant mortality rate by 0.13 percent in the long run. At the same time, it does not have any significant impact on infant mortality rate in the short term. (vii) institutional quality has a positive impact on infant mortality rate in the long run, while an insignificant negative relationship was confirmed in the short run. Also, in the short run at lag one, institutional quality has found to reduce infant mortality significantly. (viii) The coefficient value of ECM is negative and statistically significant at 1 per cent level of significance which implies that the results support the existence of a long-run association between all the variables used in this study. It also suggests that approximately 49 per cent of the short-run disequilibrium is corrected in the long run.

According to the robustness, the coefficient of R-squared value is 0.93 which implies that the variables trade openness, economic growth, foreign direct investment Inflows, financial deepening, consumer price index, education and infrastructure development, institutional quality jointly account about 93 per cent of the total variation in infant mortality rate. Subsequently, the remain 7 per cent may be due to other factors such as unstable rainfall. The adjusted coefficient of determination (R2) value of 0.88 implies that per cent of the total variation in infant mortality rate is explained by the change in the endogenous variables when the coefficient of determination is adjusted for the degree of freedom. The F-statistic value of 17.57 is significant at 5 per cent level of significance with a probability value of 0.00 implies that the model is a good fit. The Durbin- Watson statistic value of 2.45 indicates absence of auto-correlation in the estimated model. Moreover, serial correlation, heteroscedasticity, normality and Ramsey RESET tests are performed to check the model. The results conclude that there is neither serial correlation nor heteroscedasticity and anomaly. This implies that that the model has no problem.

\subsubsection{Discussion of the Empirical Results on the Relationship between Trade Liberalization and Life Expectancy}

The results presented in Table 3 for model 3 show that trade openness has a negative and insignificant in the long run, while it is positive and statically significant in the short run. This suggests that an increase in trade openness does not have significantly affect life expectancy in the long run, but increase it by 0.01 in the short run. The long-run result is contrary to expected sign and findings of Novignon et al. (2018); while consistent with the findings of Magombeyi and Odhiambo (2017), and Borlow (2018). Like infant mortality rate, this may be due to the fact most of the poor people are not directly linked to Mali merchandises exports in long-run. The short-run result may be because of medical goods imports such as mosquito nets and antimalarial drugs.

With regards to the control variables, (i) GDP per capita is found to have a positive and significant impact in both the long-run and short-run, while the table shows a negative relationship between GDP per capita and life expectancy in the short run at lag one. This implies that an increase in GDP per capita by 1 per cent increase life expectancy (or decrease poverty levels) respectively by 0.22 per cent and 0.07 per cent in both the long-run and the short-run. (ii) FDI has a negative and statistically insignificant impact on life expectancy in the long run, while positive and statistically relationship is found in the short run. This suggests that an increase in foreign direct investment does not significantly influence life expectancy in the long run, but aid to increase it in the short run. (iii) Financial deepening has a positive relationship with life expectancy in both long run and short run, but it is statistically significant in the short-run. This suggests financial deepening does not influence life expectancy in the long run, while increasing it by 0.03 per cent in the short-run. (iv) Education (proxy by gross 
secondary school enrollment) has a positive and statistically significant relationship with life expectancy in both the long run and short run. This suggests that an increase in education will increase life expectancy in Mali, respectively by 0.09 per cent and 0.03 per cent in the long run and short run. (v) Consumer price index has a negative and insignificant impact on life expectancy in the long run, while a positive and significant impact is revealed in the short run. This implies that an increase in consumer price index does not significantly life expectancy in the long-run while increasing it by t 0.07 per cent in the short run. (vi) Infrastructure development has a negative and insignificant impact on life expectancy in the long run while positively impact it in the short-run. This implies that an increase of infrastructure development by 1 percent does not play any significant role in life expectancy in the long run but increases it by 0.01 percent in the short-run. (vii) Institutional quality has a negative impact on life expectancy in both the long run and short run, but statistically significant only in the long-run. Additionally, in the short-run at lag one, the table 5 shows a significantly positive association between institutional quality and life expectancy. (viii) the coefficient value of ECM is negative and statistically significant at 1 per cent level of significance which implies that the results support the existence of a long-run association between all the variables used in this study. It also suggests that approximately 66 per cent of the short-run disequilibrium is corrected in the long run.

According to the robustness, the coefficient of R-squared value is 0.94 which implies that the independent variables jointly account about 94 percent of the total variation in life expectancy. Subsequently, the remain 6 per cent may be due to other factors such as unstable rainfall. The adjusted coefficient of determination (R2) value of 0.88 implies that per cent of the total variation in life expectancy is explained by the change in the endogenous variables when the coefficient of determination is adjusted for the degree of freedom. The F-statistic value of 16.13 is significant at 5 per cent level of significance with a probability value of 0.00 implies that the model is a good fit. The Durbin- Watson statistic value of 2.39 indicates absence of auto-correlation in the estimated model. Moreover, serial correlation, heteroscedasticity, normality and Ramsey RESET tests are performed to check the model. The results conclude that there is neither serial correlation nor heteroscedasticity and anomaly. This implies that that the model has no problem.

\subsection{Stability Test}

Finally, Figure 1,2 and 3 present the results of stability test for models 1, 2 and 3. The cumulative sum of recursive residuals (CUSUM) and the cumulative sum of recursive residuals square (CUSUMSQ) are employed to check the stability of the three models. From the figures below, it can be seen that the plots of CUSUM and CUSUMQ are within the 5 per cent significance lines or boundaries, which suggests that the residual variance of all the models is somewhat stable, hence also confirming the stability of the three models.
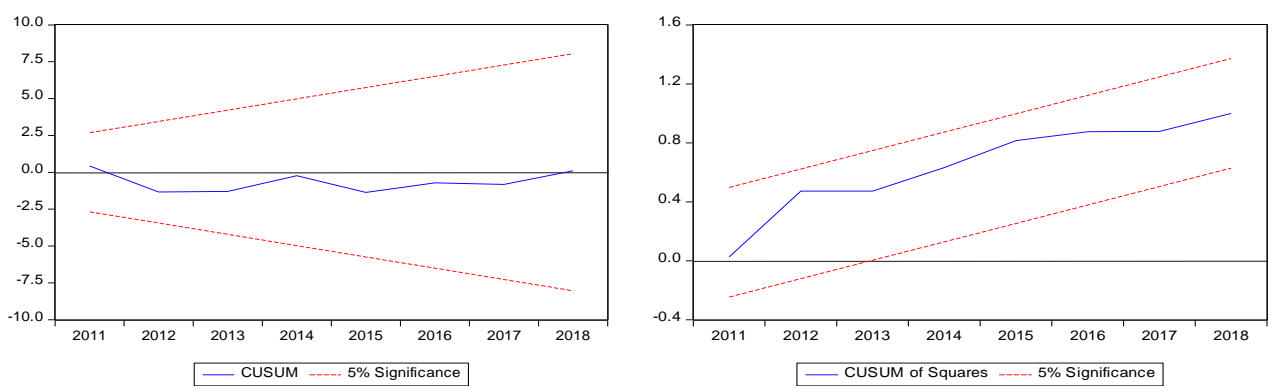

Figure 1. Plot of CUSUM and CUSUMSQ for model using Per capita consumption
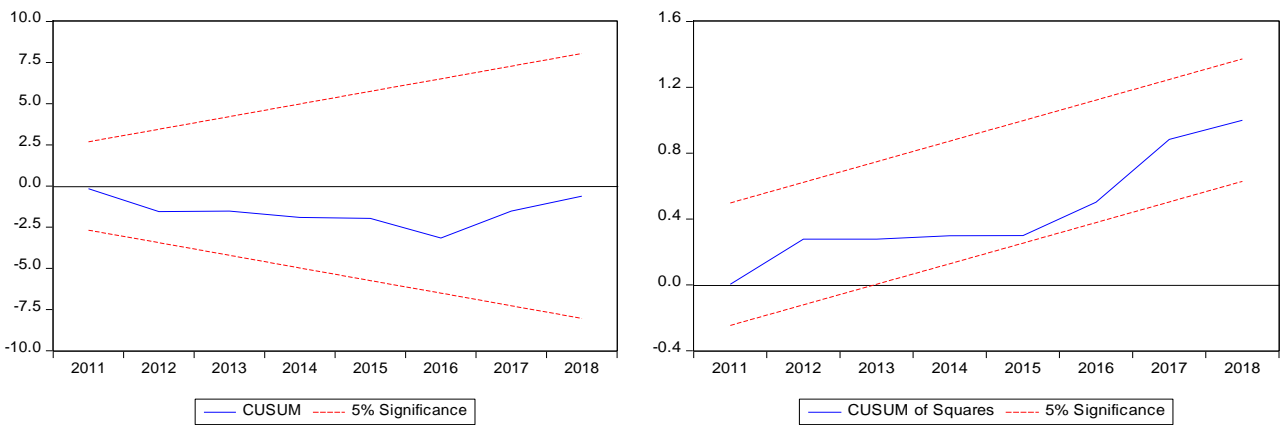

Figure 2. Plot of CUSUM and CUSUMSQ for model using Infant Mortality Rate 

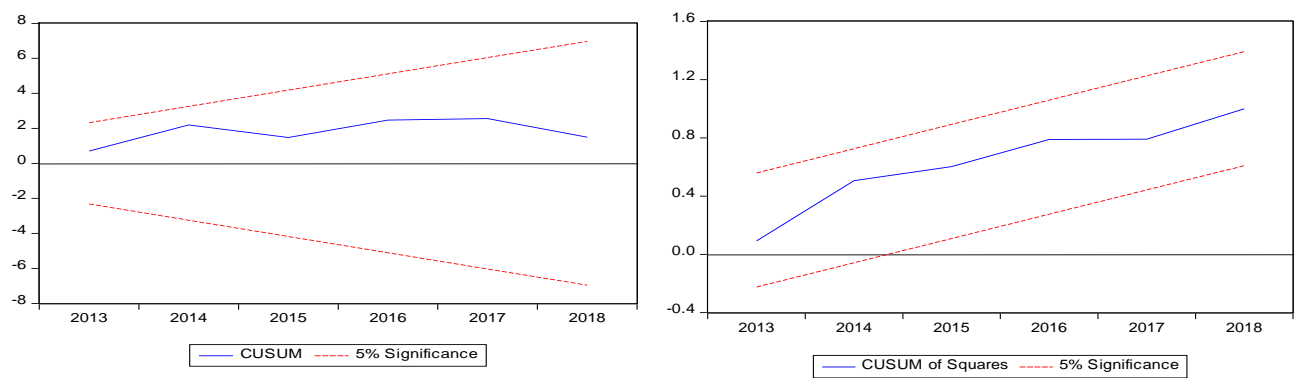

Figure 3. Plot of CUSUM and CUSUMSQ for model using life expectancy

\section{Conclusion and Policy Recommendations}

The main objective of our study was to investigate the long-run and short-run impact of trade liberalization on poverty reduction in Mali during the period 1986-2018. It was done by using the ARDL bounds test. The results indicated that trade liberalization increases poverty reduction in Mali in the long-run and reduce it in the short-run. Similarly, variables such as financial deepening, education, infrastructure development, and institutional quality tend to increase poverty in the long run and reduce it in the short-run. This confirms that the impact of trade liberalization on poverty reduction depends on complementary policies.

In order to benefit the positive effect of trade liberalization, the government of Mali should diversify its exports by increasing the number of export products and partners. Also, the government must add value most of the primary commodities in which it has a comparative advantage. Therefore, the quality of education must be improved by increasing the number of schools, qualified teachers, and low skill labour training, particularly in rural areas. It must particularly invest more in women education. This will not only increase their employment opportunities but will help to reduce child mortality.Through the private sector guarantee fund, access to medium and long-run credit must be improved, especially to poor people and small and medium enterprises. A massive investment must be made in the infrastructure sector (mainly road, railway, energy, telecommunication, water, slaughterhouse, and so on) in order to reduce transaction costs and improve export competitiveness. The quality of the institution must be enhanced through the fight of corruption and consolidation of democracy. Following Mauritius and Ethiopia, the export processing zone should be established to attract more foreign investment in low-skilled labour-intensive industries (such as textile and agro-business). Finally, regional integration policies should be pursued and strengthened by the government through regional infrastructure projects and standardization of border procedures. This is critical because, as a landlocked country, Mali requires secure access to ports and to quality port services in neighbouring countries.

\section{References}

Abdullahi, O., Safiyanu, S., \& Soja, T. (2013). International Trade and Economic Growth: Empirical Analysis of West Africa. Journal of Economic and Finance, 7, 12-15.

Agusalim, L., \& Pohan, F, Z. (2018). Trade Openness Effect on Income Inequality: Empirical Evidence from Indonesia. Jurnal Ilmu Ekonomi, 7(1), 1-14. https://doi.org/10.15408/sjie.v7i1.5527

Akmal, M., Ahmad, Q., Ahmad, M., \& Bult, S. (2017). Empirical Investigation of the Relationship between Trade Openness and Poverty Reduction: Case for Pakistan. The Lahore Journal of Economics, 12(1), 99-118. https://doi.org/10.35536/lje.2007.v12.i1.a5

Amadou, A. (2013). Is there a Causal Relationship between Trade Openness and Economic Growth in the WAEMU Countries? International Journal of Economics and Finance, 5, 151-156. https://doi.org/10.5539/ijef.v5n6p151

Ayinde, O. (2013). Trade Liberalization, Growth, and Poverty Reduction in Nigeria. Journal of Economics and Sustainable Development, 4(18).

Badolo, F., \& Traore, F. (2012). Impact of Rising of World Rice Prices on Poverty and Inequality in Burkina Faso. CERDI, Etudes et Documents, E 2012.22.

Barlow, P. (2018). Does trade liberalization reduce child mortality in low- and middle-income countries? Synthetic control analysis of 36 policy experiments, 1963-2005. Social Science \& Medicine, 205, 107-115. https://doi.org/10.1016/j.socscimed.2018.04.001

Bekele, Y. E. (2017). Exploring the Relationship between Trade Liberalization and Ethiopian Economic Growth. 
Master Dissertation, University Antwerpen.

Berg, A., \& Krueger, A.(2003). Trade, Growth, and Poverty: A Selective Survey. I.M.F. Working Paper WP/03/03. https://doi.org/10.5089/9781451844931.001

Bhagwati, J., \& Srinivasan, T.N.(2002). Trade and Poverty in the Poor Countries. American Economic Reviews, 92(2), 180-183. https://doi.org/10.1257/000282802320189212

Bonga-Bonga, L., \& Kinfack, E.(2019). The growth effect of trade openness on African countries: evidence from using an Instrumental Variable Panel Smooth Transition Model. Munich Personal RePEc Archive No. 65537 No. 92111.

Delleur, P. (2005). Commerce, Croissance et Reduction de la Pauvrete. Politique étrangère, 373-385. https://doi.org/10.3917/pe.052.0373

Dollar, D., \& Kraay, A. (2004). Trade, Growth, and Poverty. The Economic Journal, 114, F22-F49. https://doi.org/10.1111/j.0013-0133.2004.00186.x

Duncan, R., \& Quang, D. (2003). Trade Liberalization, Economic Growth, and Poverty Reduction Strategies. National Centre for Development Studies, The Australian National University.

Dursun, G., \& Ogunleye, B. (2016). Economic Growth, Employment, and Poverty Reduction: Case of West African countries. The American Journal of Economics, 6(1), 50-60.

Farooq, F., Yusop, Z., \& Chaudhry, S. (2019). How do trade openness and public expenditures affect health status in O.I.C. member countries? An empirical analysis. Journal of Commerce and Social Sciences of Pakistan, 13(4), 1041-1056.

Grossman, G. M., \& Helpman, E. (1990). Comparative Advantage of Long-Run Growth. The American Economic Review, 80(4), 796-815.

Grossman, M., \& Helpman, E. (1990). Trade, Knowledge Spillovers, and Growth. NBER Working Paper No.3485. https://doi.org/10.3386/w3485

Gunther, I., Marouani, M., \& Raffinot, M. (2006). La Croissance est-elle pro-pauvres au Mali? Document de Travail DT/2006-15.

Jawadi, F., El Gouddi, S., \& Ftiti, Z. (2018). Assessing the Effect of Trade Openness on Health in the Middle East and North Africa(MENA) Region: A Panel Data Analysis. Open Economic Review, 29, 469-479. https://doi.org/10.1007/s11079-017-9450-3

Kelbore, Z. G. (2015). Trade Openness, Structural transformation, and Poverty Reduction: Empirical Evidence from Africa. Munich Personal RePEc Archive No. 65537.

Kray, A. (2001). Growth is good for the poor. Journal of Economic Growth, 7(3), 195-225.

Le Goff, M., \& Singh, R. J. (2014). Does trade reduce poverty? A view for Africa. Journal of African Trade, 1, 5-14. https://doi.org/10.1016/j.joat.2014.06.001

Okungbowa, F., \& Eburajolo, O. (2014). Globalization and poverty rate in Nigeria: An empirical analysis. International Journal of Humanities and Social Science, 4(11), 126-135.

Onakoya, A., Johnson, B., \& Ogundajo, G. (2019). Poverty and trade liberalization: Empirical evidence from 21 African countries. Economic Research, 32(1), 635-656. https://doi.org/10.1080/1331677X.2018.1561320

Phillips, P. C. B., \& Perron, P. (1988). Testing for a unit root in times series regression. Biometrica, 75, 335-446. https://doi.org/10.1093/biomet/75.2.335

Rivera-Batiz, L. A., \& Romer, P. M. (1991). International Trade with Endogenous Technological Change. NBER Working Paper No.3594. https://doi.org/10.3386/w3594

Rivera-Batiz, L.A., \& Romer, P. M. (1990). Economic Integration and Endogenous growth. NBER Working Paper No.3528. https://doi.org/10.3386/w3528

Young, A. (1991). Learning by Doing and the Dynamic Effects of International Trade. NBER Working Paper No.3577. https://doi.org/10.3386/w3577

Yusuf, M., Khin, A., \& Malarvizhi, C. (2013). Trade Liberalization Economic Growth and Poverty Reduction in Nigeria. International Journal of Business and Management, 8(12). https://doi.org/10.5539/ijbm.v8n12p42 


\section{Copyrights}

Copyright for this article is retained by the author(s), with first publication rights granted to the journal.

This is an open-access article distributed under the terms and conditions of the Creative Commons Attribution license (http://creativecommons.org/licenses/by/4.0/). 